\title{
Saving Private Money
}

\section{Ahorrando dinero privado}

\author{
M. Sivaram ${ }^{1}$, B. Ayshwarya ${ }^{2}$, Muhammad Rizky Pribadi ${ }^{3}$, Phong Thanh \\ Nguyen $^{4}$, K. Shankar ${ }^{5}$, Amin Salih Mohammed ${ }^{1}$, Satria Abadi ${ }^{3}$, Miftachul \\ Huda $^{6}$, Dian Permana Putra ${ }^{3}$, Wahidah Hashim ${ }^{7}$, Andino Maseleno ${ }^{{ }^{*}}, \mathrm{~V}$. \\ Porkodi $^{1}$, V. Manikandan' ${ }^{1}$, Andrei V. Ochepovsky ${ }^{8}$ \\ ${ }^{1}$ Assistant Professor, Department of Computer Networking, Lebanese French \\ University, Erbil, Iraq. \\ ${ }^{2}$ Department of Computer Science, Kristu Jayanti College, Bangalore-560043, \\ India. \\ ${ }^{3}$ Department of Information Systems, STMIK Pringsewu, Lampung, Indonesia. \\ ${ }^{4}$ Department of Project Management, Ho Chi Minh City Open University \\ (HCMCOU), Vietnam. \\ ${ }^{5}$ School of Computing, Kalasalingam Academy of Research and Education, \\ Krishnankoil, India. \\ ${ }^{6}$ Universiti Pendidikan Sultan Idris, Malaysia. \\ ${ }^{7}$ Institute of Informatics and Computing Energy, Universiti Tenaga Nasional, \\ Malaysia. \\ andimaseleno@gmail.com \\ ${ }^{8}$ Togliatti State University, Russia
}

Enviado: 27 de junio de 2019

Aceptado para publicar: 30 de julio de 2019

Publicado: 8 de agosto de 2019

\section{abstract}

The savings and cash withdrawal application information system that runs on the new Bandung BMT el-ihsan KJKS it is still conventional so there are several problems in handling the process of presenting financial reports include delays in service to customers, and often occur reporting and recording errors. The main objective of this research is to present the system. Information in the form of applications that can be used to suit your needs. New system design using structured techniques where the system is modeled with a data flow diagram, database modeled using Entity Relationship Diagram (ERD). Input application creation savings and cash withdrawals in the new KJKS BMT el-ihsan Bandung using a programming language dhelphi 7 and $\mathrm{ms}$ access database. This research produces applications for savings and drag inputs cash, and with a new system can optimize the computer system in the process service to customers and reporting so that they can manage data well, for produce information that is easier and more accurate.

Keywords: saving, cash withdrawal, information system

El sistema de información de la aplicación de ahorro y retiro de efectivo que se ejecuta en el nuevo Bandung BMT el-ihsan KJKS sigue siendo convencional, por lo que hay varios problemas en el manejo del proceso de presentación de informes financieros, que incluyen retrasos en el servicio a los clientes, y a menudo ocurren errores de informes y registro. El objetivo principal de esta investigación es presentar el sistema. Información en forma de aplicaciones que se pueden utilizar para satisfacer sus necesidades. Nuevo diseño del sistema usando técnicas estructuradas donde el sistema se modela con un diagrama de flujo de datos, una base de datos modelada usando el Diagrama de Relación de Entidades (ERD). Ingrese ahorros de creación de aplicaciones y retiros de efectivo en el nuevo KJKS BMT el-ihsan Bandung utilizando un lenguaje de programación dhelphi 7 y una base de datos de acceso ms. Esta investigación produce aplicaciones para ahorrar y arrastrar entradas de efectivo, y con un nuevo sistema puede optimizar el sistema informático en el servicio de proceso a los clientes y los informes para que puedan administrar bien los datos, para producir información que sea más fácil y más precisa.

Palabras clave: ahorro, retiro de efectivo, sistema de información. 


\section{Introduction}

\subsection{Background}

At the present, the computer refers to the modern technology with the sufficiently sophisticated system of committing the efficiency on the device needed to apply for data processing and presenting a information easily, quickly and accurately $[1][2][3][4]$. With this information is expected to be overcome problems in data management $[5][6][7][8]$, in that there could help make it easier and easier data management and information presentation [9][10][11][12]. The use of information technology by an institution can accelerate information access, timeliness presenting and producing information accurate and can provide services effective and efficient $[13][14][15][16]$. The cooperation service of Islamic financial system points out disseminating the mutual service through adopting the technology attribution $[[17][18][19][20]$. In increasing the customer service with the wide contribution of financial service under the technology enhancement [21][22][23][24], attempts to provide information services should bring along with determining the appropriate chance for the customers [25][26][27][28]. In particular, the wide point of necessary to apply for the further elaboration in the attempts to input cash withdrawals and savings making financial statements [29][30][31][32]. Thus, both savings and reporting are engaged into the conventional basis which causes the entire employees on duty to experience difficulties [33][34][35][36] together with the commitment of recording and reporting errors solving in the systematic approach basis of information system [37][38][39][40].

\subsection{Problem Formulation}

Based on the background the formulation described above can be taken problem, the main concern refers to the way on how to make a program Savings and drag input system applications cash using Delphi for the language programming. This can help and facilitate the process of managing balance data Savings partner, storage and Submission of information in inputting savings and cash withdrawals at the Islamic financial platform (BMT), in one particular state of Bandung, Indonesia.

\subsection{Limitation of Problems}

a. The object of this research is BMT KJKS el-ihsan bandung new.

b. The system is built about the system savings and cash withdrawal input

c. Making an application system on KJKS BMT el-ihsan bandung new Regency Pringsewu uses language Delphi programming is a language programming that is created or on make it through the Form page, generally used to process data in computer and facilitate work a usser (user).

d. Processing data information from BMT el ihsan employees

\subsection{Purpose}

a. Generate savings input application and cash withdrawals that can provide solutions and alternative means.

b. Can build or determine savings and cash withdrawal information system which is better to apply especially for customers.

c. Determine problems and provide settlement in the form of an information system effective and efficient.

d. To help the processing process savings quickly, precisely and accurately.

e. To facilitate internal employees process processing data in data storage.

f. Helps in improving performance employees and also provide accurate information in manufacture necessary reports

\subsection{Benefits of Research}

With the Application System inputting savings can help employees in managing savings customer.

\section{Literaturer Review}

\subsection{Definition of System}

The system is a network of work procedure mutual procedures connect, gather together to do an activity or complete a specific goal $[41][42][43]$. Through expanding the systematic approach of disseminating the planning with implementing this approach [44][45][46][47], the point refers to enhance the entire interaction for each other in reaching the certain goal through three stages, namely input, process and output [48][49][50][51]. With the group-based teamwork commitment to consider the mutual interconnected components [52][53][54], to lead to work together to achieve common goals with receive input and produce output in a regular transformation [55][56][57]. As the set of objects to give insightful value of working together produce methods, procedures, techniques combined and arranged [58][59][60], the entire process with the multiple unit to function in achieving the mutual goal is recorded, grouped, and saved but not organized for convey a certain meaning [61][62][63]. In particular, the Information Data refers to the attempts of the process with more useful form for recipient. Data is a fact that is not moderate used in the decision process, usually recorded and archived without intent soon taken back for information [64][65]. Data is plural of forms single or item data, data is information that is still in raw form which cannot 
be told, so need to be processed further [66][67][68][69. Data can defined as reality described by number values numbers, strands of characters or symbols that carry a certain meaning $[70][71][72][73]$. Information is the result of data processing in a more meaningful form useful for the recipient, which is used as a tool for retrieval decision [74][75][76][77].

\subsection{Database}

The database is a collection of scattered data which are logically related, and an explanation of this data is designed for meet the information needs of one organization. Database is a set of data organized for Support many applications efficiently by centralizing data and controlling redundant data. Database is the most important component, because as a place to accommodate and organize all the data is in the system, so it can explored to compile information in various forms. Database also known as bankdata. Database is a set of data groups each other related.

Data that organized in such a way that can be processed or explored quickly and easy to produce information [78][79][80].

\section{Analysis and Design}

\subsection{Analysis}

\subsubsection{Old System Analysis}

After making observations directly and hold observation with employees of KJKS BMT elihsan, and see the available data in recording financial statements / balances, then the system description is obtained walk in KJKS BMT elihsan bandung new. Based on the system description this, obtained several problems which needs to be analyzed. Medium system running mainly about information BMT's financial statements are currently still is manual which means recording still written or recorded in the book big. Then it will be made application for savings and cash withdrawal input which will be implemented on KJKS BMT el ihsan bandung new paragraphs must be justified alignment. With justified alignment, both sides of the paragraph are straight.

\subsubsection{Analysis of New System Needs}

\subsubsection{Functional Needs}

The system can provide applications for officers namely employees who are have access rights as follows:

1. Can see all available data in the application.

2. Officers can input all balance data and make transactions in application.

3. The system can provide information financial statement / balance.

3.1.2.2. Nonfunctional needs
Hardware needed is a desktop PC, or notebook with the following specifications:

1. a minimum of $512 \mathrm{MB}$ RAM.

2. Software what the system needs is Borland Delphi 7 as a language programming. And also a Database Access 2007.

3. Windows XP or Operating System Windows 7.

\subsubsection{Designing Data Base}

Database in the Input Application Program. This savings and cash withdrawal consists of some tables that need to be made are:

a. Table for inputting new customer data.

b. Savings transaction data input table and cash withdrawal.

c. Login settings table like user and password replacement.

d. Savings balance report data table customers during transactions.

e. Print table saving and drag slips cash, as proof of transaction

\section{Implementation}

\subsection{System Implementation}

After doing the design stage and making applications, the next stage implement and test system which is the final stage on this study then conducted a trial functionality program to administrator as user.

\subsection{Login Page}

Figure 1 shows login page

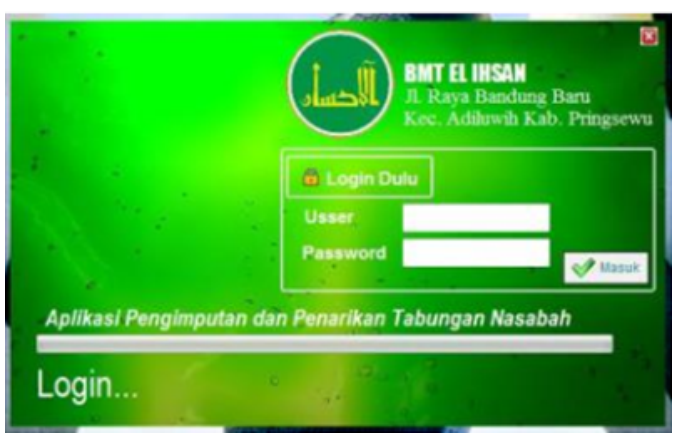

Figure 1. Login page

\subsection{Main Menu Page}

Figure 2 shows main menu page 


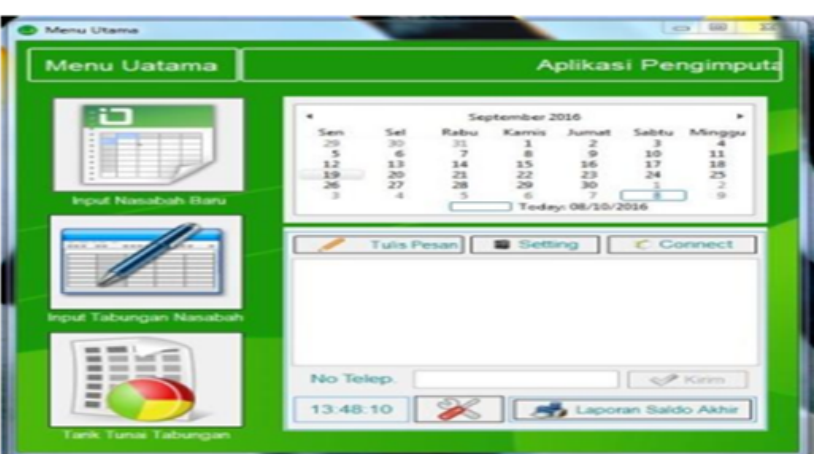

Figure 2. Main menu page

\subsection{New customer input page}

Figure 3 shows new customer input page.

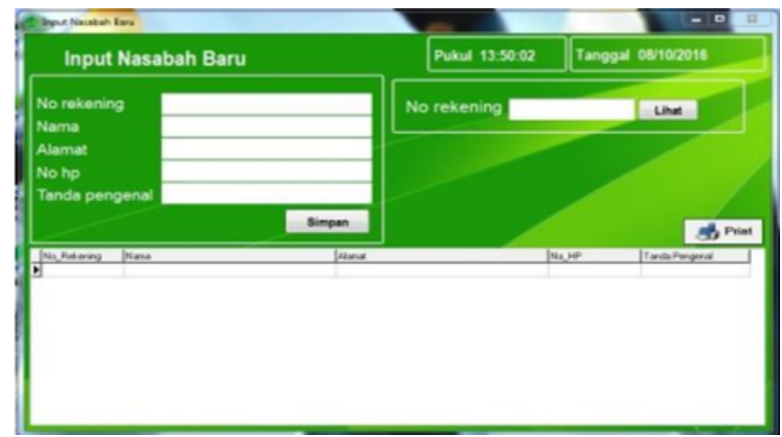

Figure 3. New customer input page

\subsection{Saving input page}

Figure 4 shows saving input page

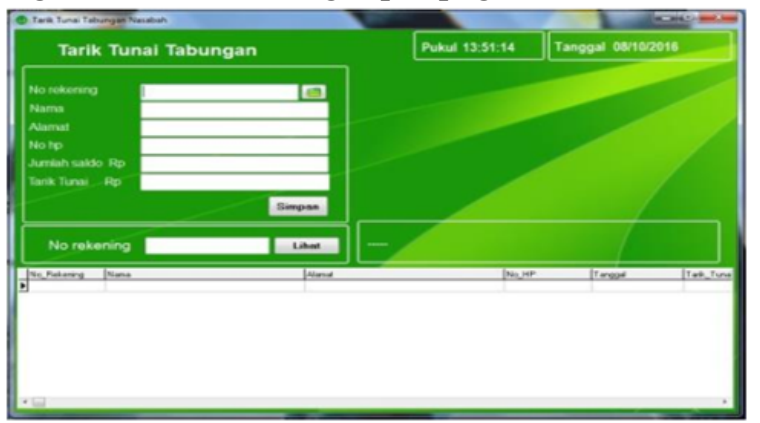

Figure 4. Saving input page

\subsection{Cash withdrawal savings}

Figure 5 shows cash withdrawal saving page

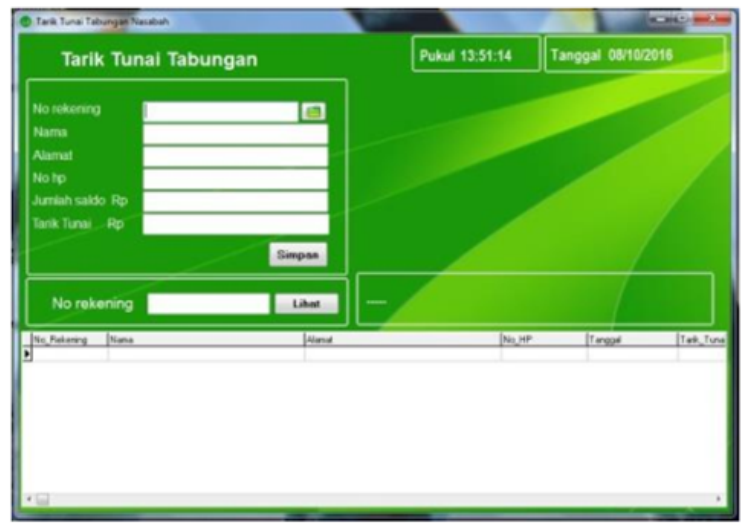

Figure 5. Cash withdrawal saving page

\subsection{Report print page}

Figure 6 shows report print page

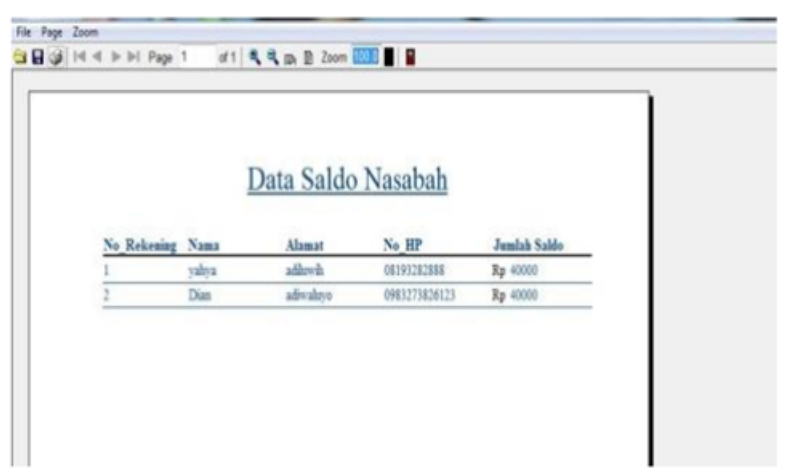

Fig. 6. Report print page

\subsection{Login settings page}

Figure 7 shows login setttings page

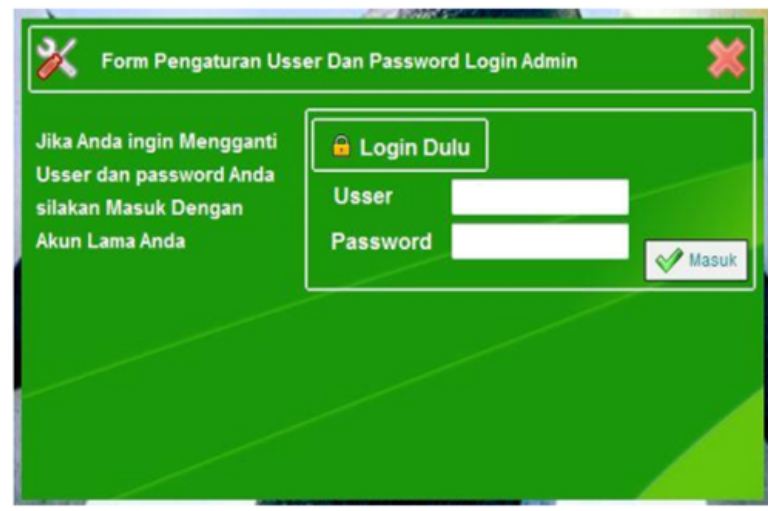

The main page is the page for find out the features available in Sitsem, the input page works as inputting data for all customers as well as customer transaction data input saving and taking savings.

\section{Conclusions}

With the input application made savings and cash withdrawals using Delphi on KJKS BMT EL IHSAN it can help the officer inside manage and input data finance and to accelerate the process of searching and compiling data, especially in data collection and can accelerate employee work processes. The savings input application system and cash withdrawals at BMT KJKS EL IHSAN can really help employee work, to accelerate the process of imposing savings and attraction cash customers who are in the transaction because it uses an output system in the form of receipts or print evidence transaction.

\section{References}

Huda, M., Anshari, M., Almunawar, M. N., Shahrill, M., Tan, A., Jaidin, J. H., ... \& Masri, M. (2016). Innovative Teaching in 
Higher Education: The Big Data Approach. The Turkish Online Journal of Educational Technology, 15(Special issue), 1210-1216.

Othman, R., Shahrill, M., Mundia, L., Tan, A., \& Huda, M. (2016). Investigating the Relationship Between the Student's Ability and Learning Preferences: Evidence from Year 7 Mathematics Students. The New Educational Review, 44(2), 125-138.

Zakirillah, Noorminshah, A. I., Huda, M., Fathoni, \& and Heroza, R. I. (2016). Design of a Mobile based Academic Cyber Counselling Application in Higher Education. Journal of Information Systems Research and Innovation, 10(3), 1-9.

Anshari, M., Almunawar, M. N., Shahrill, M., Wicaksono, D. K., \& Huda, M. (2017). Smartphones usage in the classrooms: Learning aid or interference?. Education and Information Technologies, 22(6), 30633079 .

Huda, M., Sabani, N., Shahrill, M., Jasmi, K. A., Basiron, B., \& Mustari, M. I. (2017a). Empowering Learning Culture as Student Identity Construction in Higher Education. In A. Shahriar, \& G. Syed (Eds.), Student Culture and Identity in Higher Education (pp. 160-179). Hershey, PA: IGI Global. doi:10.4018/978-1-5225-2551-6.ch010

Huda, M., Jasmi, K. A., Hẹsan, A., Shahrill, M., Mustari, M. I., Basiron, B., \& Gassama, S. K. (2017b). Empowering Children with Adaptive Technology Skills: Careful Engagement in the Digital Information Age. International Electronic Journal of Elementary Education, 9(3), 693708 .

Huda, M., Shahrill, M., Maseleno, A., Jasmi, K. A., Mustari, I., \& and Basiron, B. (2017c). Exploring Adaptive Teaching Competencies in Big Data Era. International Journal of Emerging Technologies in Learning, 12(3), 68-83.

Huda, M., Jasmi, K. A., Basiran, B., Mustari, M. I. B., \& Sabani, A. N. (2017d). Traditional Wisdom on Sustainable Learning: An Insightful View From AlZarnuji's Ta 'lim al-Muta 'allim. SAGE Open, 7(1), 1-8.

Huda, M., Jasmi, K. A., Embong, W. H., Safar, J., Mohamad, A. M., Mohamed, A.' K., Muhamad, N. H., Alas, Y., \& Rahman, S. K. (2017e). Nurturing Compassion-Based Empathy: Innovative Approach in Higher Education. In M. Badea, \& M. Suditu (Eds.), Violence Prevention and Safety Promotion in Higher Education Settings (pp. 154-173). Hershey, PA: IGI Global. doi:10.4018/9781-5225-2960-6.ch009

Huda, M., Jasmi, K. A., Alas, Y., Qodriah, S. L. Dacholfany, M. I., \& Jamsari, E. A. (2017f). Empowering Civic Responsibility: Insights From Service Learning. In $S$. Burton (Ed.), Engaged Scholarship and Civic Responsibility in Higher Education(pp. 144-165). Hershey, PA: IGI Global. doi:10.4018/978-1-5225-36499.ch007

Huda, M., Jasmi, K. A., Mustari, M. I., Basiron, B., Mohamed, A. K., Embong, W., ... \& Safar, J. (2017g). Innovative E-Therapy Service in Higher Education: Mobile Application Design. International Journal of Interactive Mobile Technologies, 11(4), 8394.
Huda, M., Jasmi, K. A., Mustari, M. I., \& Basiron, B. (2017h). Understanding Divine Pedagogy in Teacher Education: Insights from Al-zarnuji's Ta'lim Al-Muta'Allim. The Social Sciences, 12(4), 674-679.

Huda, M., Jasmi, K. A., Mustari, M. I. B., \& Basiron, A. B. (2017i). Understanding of Wara' (Godliness) as a Feature of Character and Religious Education. The Social Sciences, 12(6), 1106-1111.

Huda, M., Siregar, M., Ramlan, Rahman, S.K.A., Mat Teh, K.S., Said, H., Jamsari, E.A., Yacub, J., Dacholfany, M.I., \& Ninsiana, W. (2017j). From Live Interaction to Virtual Interaction: An Exposure on the Moral Engagement in the Digital Era. Journal of Theoretical and Applied Information Technology , 95(19), 49644972.

Huda, M., Maseleno, A., Jasmi, K. A., Mustari, I., \& Basiron, B. (2017k). Strengthening Interaction from Direct to Virtual Basis: Insights from Ethical and Professional Empowerment. International Journal of Applied Engineering Research, 12(17), 6901-6909.

Huda, M., Haron, Z., Ripin, M. N., Hehsan, A., \& Yaacob, A. B. C. (20171). Exploring Innovative Learning Environment (ILE): Big Data Era. International Journal of Applied Engineering Research, 12(17), 6678-6685.

Maseleno, A., Huda, M., Siregar, M., Ahmad, R., Hehsan, A., Haron, Z., Ripin, M.N., Ihwani, S.S., and Jasmi, K.A.'(2017). Combining the Previous Measure of

Evidence to Educational Entrance Examination. Journal of Artificial Intelligence 10(3), 85-90.

Adela, H., Jasmi, K.A., Basiron, B., Huda, M., Maseleno, A. (2018). Selection of dancer member using simple additive weighting. International Journal of Engineering \& Technology. 7(3). 10961107.

Aminin, S., Huda, M., Ninsiana, W., and Dacholfany, M.I. (2018). Sustaining civicbased moral values: Insights from language learning and literature. International Journal of Civil Engineering and Technology. 9(4), 157-174.

Amin, M.M., Nugratama, M.A.A., Maseleno, A., Huda, M., Jasmi, K.A.' (2018). Design of cigarette disposal blower and automatic freshner using mq-5 sensor based on atmega 8535 microcontroller. International Journal of Engineering \& Technology. 7(3). 1108-1113

Assahubulkahfi, M., Sam, Y. M., Maseleno, A., \& Huda, M. (2018). LQR Tuning by Particle Swarm Optimization of Full Car Suspension System. International Journal of Engineering \& Technology, 7(2.13), 328331 .

Atmotiyoso, P. and Huda, M. (2018). Investigating Factors Influencing Work Performance on Mathematics Teaching: A Case Study. International Journal of Instruction. 11(3), 391-402

Huda, M., \& Teh, K. S. M. (2018). Empowering Professional and Ethical Competence on Reflective Teaching Practice in Digital Era. In Dikilitas, K., Mede, E., Atay D. (Eds). Mentorship Strategies in Teacher Education (pp. 136-152). Hershey, PA: IGI Global. do1: 10.4018/978-1-5225- 
4050-2.ch007

Huda, M., Teh, K.S.M., Nor, N.H.M., and Nor, M.B.M. (2018a). Transmitting Leadership Based Civic Responsibility: Insights from Service Learning. International Journal of Ethics and Systems, 34(1), 20-31. DOI: 10.1108/IJOES-05-20170079

Huda, M., Mulyadi, D., Hananto, A. L., Nor Muhamad, N. H., Mat Teh, K. S., \& Don, A. G. (2018). Empowering corporate social responsibility (CSR): insights from service learning. Social Responsibility Journal, 14(4), 875-894.

Huda, M., Maseleno, A., Muhamad, N.H.N., Jasmi, K.A., Ahmad, A., Mustari, M.I., Basiron, B.' (2018b). Big Data Emerging Technology: Insights into Innovative Environment for Online Learning
Resources. International Journal of Emerging Technologies in Learning 13(1), 23-36. doi:10.3991/ijet.v13i01.6990

Huda, M., Maseleno, A., Teh, K.S.M., Don, A.G., Basiron, B., Jasmi, K.A., Mustari, M.I., Nasir, B.M., and Ahmad, R. (2018c). Understanding Modern Learning Environment (MLE) in Big Data Era. International Journal of Emerging Technologies in Learning. 13(5), 71-85. doi: 10.3991/ijet.v13i05.8042

Huda, M. (2018). Empowering Application Strategy in the Technology Adoption: Insights from Professional and Ethical Engagement. Journal of Science and Technology Policy Management. doi.org/10.1108/JSTPM-09-2017-0044.

Huda., M. \& Sabani, N. (2018). Empowering Muslim Children's Spirituality in Malay Archipelago: Integration between National Philosophical Foundations and Tawakkul (Trust in God). International Journal of Children's Spirituality, 23(1), 8194.

Huda, M., Almunawar, M. N., Hananto, A. L., Rismayadi, B., Jasmi, K. A., Basiron, B., \& Mustari, M. I. (2018). Strengthening Quality Initiative for Organization Stability: Insights From Trust in Cyberspace-Based Information Quality. In Cases on Quality Initiatives for Organizational Longevity ( $p p$. 140-169 Hershey, PA: IGI Global. DOI: 10.4018/978-1-5225-5288-8.ch006

Huda, M., Qodriah, S.L., Rismayadi, B., Hananto, A., Kardiyati, E.N., Ruskam, A., and Nasir, B.M. (2019). Towards Cooperative with Competitive Alliance: Insights into Performance Value in Social Entrepreneurship. In Creating Business Value and Competitive Advantage with Social Entrepreneurship. (pp.294). Hershey, PA: IGI Global. DOI: 10.4018/978-1-52255687-9.ch014

Huda, M., Hehsan, A., Basuki, S., Rismayadi, B., Jasmi, K. A., Basiron, B., \& Mustari, M. I. (2019). Empowering Technology Use to Promote Virtual Violence Prevention in Higher Education Context. In Intimacy and Developing Personal Relationships in the Virtual World (pp. 272-291). Hershey, PA: IGI Global. DOI: $10.4018 / 978-1-5225-4047-2$.ch015

Huda, M., Ulfatmi, Luthfi, M.J., Jasmi, K.A., Basiron, B., Mustari, M.I., Safar, A., Embong, H.W.H., Mohamad, A.M., and Mohamed, A.K. (2019). Adaptive online learning technology: Trends in big data era.
In Diverse Learning Opportunities Through Technology-Based Curriculum Design. (pp.163-195), Hershey, PA: IGI Global. DOI: $10.4018 / 978-1-5225-5519-3 . c h 008$

Kurniasih, D., Jasmi, K.A., Basiron, B., Huda, M., Maseleno, A. (2018). The uses of fuzzy logic method for finding agriculture and livestock value of potential village. International Journal of Engineering \& Technology. 7(3). 1091-1095.

Maseleno, A., Pardimin, Huda, M., Ramlan, Hehsan, A., Yusof, Y.M., Haron, Z., Ripin, M.N., Nor, N.H.M., and Junaidi, J. (2018a). Mathematical Theory of Evidence to Subject Expertise Diagnostic. ICIC Express Letters, 12 (4), 369 DOI: 10.24507/icicel.12.04.369

Maseleno, A., Huda, M., Jasmi, K.A., Basiron, B., Mustari, I., Don, A.G., and Ahmad, R. (2018b). Hau-Kashyap approach for student's level of expertise. Egyptian Informatics doi.org/10.1016/j.eij.2018.04.001

Maseleno, A., Sabani, N., Huda, M., Ahmad, R., Jasmi, K.A., Basiron, B. (2018c). Demystifying Learning Analytics in Personalised Learning. International Journal of Engineering \& Technology. 7(3). 11241129.

Moksin, A. I., Shahrill, M., Anshari, M., Huda, M., \& Tengah, K. A. (2018b). The Learning of Integration in Calculus Using the Autograph Technology. Advanced Science Letters, 24(1), 550-552.

Putra, D.A.D., Jasmi, K.A., Basiron, B., Huda, M., Maseleno, A.,' Shankar, K., Aminudin, N. (2018). Tactical Steps for EGovernment Development. International Journal of Pure and Applied Mathematics. 119(15). 2251-2258

Rosli, M.R.B., Salamon, H.B., and Huda, M. (2018). Distribution Management of Zakat Fund: Recommended Proposal for Asnaf Riqab in Malaysia. International Journal of Civil Engineering and Technology 9(3), pp. 56-64.

Sugiyarti, E., Jasmi, K.A., Basiron, B., Huda, M., Shankar, K., Maseleno, A. (2018). Decision support system of scholarship grantee selection using data mining. International Journal of Pure and Applied Mathematics. 119(15), 2239-2249.

Susilowati, T., Jasmi, K.A., Basiron, B., Huda, M., Shankar, K., Maseleno, A., Julia, A. Sucipto. (2018). Determination of Scholarship Recipients Using Simple Additive Weighting Method. International Journal of Pure and Applied Mathematics. 119 (15), 2231-2238.

Susilowati, T., Dacholfany, M.I., Aminin, S., Ikhwan, Å., Nasir, B.M., Huda, M., Prasetyo, A., Maseleno, A., Satria, F., Hartati, S., and Wulandari. (2018). Getting parents involved in child's school: using attendance application system based on SMS gateway. International Journal of Engineering and Technology. 7(2.27), 167174.

Susilowati, T., Teh, K.S.M., Nasir, B.M., Don, A.G., 'Huda, M., Hensafitri, T., Maseleno, A., Oktafianto, and Irawan, D. (2018). Learning application of Lampung language based on multimedia software. International Journal of Engineering and Technology. 7(2.27), 175-181. 
Abadi, S., Teh, K.S.M., Nasir, B.M., Huda, M., Ivanova, N.L., Sari, T.I., Maseleno, A., Satria, F., and Muslihudin, M. (2018). Application model of k-means clustering: insights into promotion strategy of vocational high school. International Journal of Engineering and Technology. 7 (2.27), 182-187.

Aminudin, N., Huda, M., Ihwani, S.S., Noor, S.S.M., Basiron, B., Jasmi, K.A., Safar, J., Mohamed, A.K., Embong, W.H.W., Mohamad, A.M., Maseleno, A., Masrur, M., Trisnawati, and Rohmadi, D. (2018). The family hope program using AHP method. International Journal of Engineering and Technology. 7(2.27), 188-193.

Wulandari, Aminin, S., Dacholfany, M.I., Mujib, A., Huda, M., Nasir, B.M., Maseleno, A., Sundari, E., Fauzi, and Masrur, M. '(2018). Design of library application system. International Journal of Engineering and Technology. 7(2.27), 199204.

Aminudin, N. Huda, M., Mohamed, A.K., Embong, W.H.W., Mohamad, A.M., Basiron, B., Ihwani, S.S., Noor, S.S.M., Jasmi, K.A., Safar, J., Natalie, L., Ivanova, Maseleno, A., Triono, A., and Nungsiati. (2018). Higher education selection using simple additive weighting. International Journal of Engineering and Technology. 7(2.27), 211-217.

Anggraeni, E.Y., Huda, M., Maseleno, A., Safar, J., Jasmi, K.A., Mohamed, A.K., Hehsan, A., Basiron, B., Ihwani, S.S., Embong, W.H.W., Mohamad, A.M., Noor, S..S.M., Fauzi, A.N., Wijaya, D.Ä., and Masrur, M. (2018). Poverty level grouping using SAW method. International Journal of Engineering and Technology. 7(2.27), 218224.

Abadi, S., Huda, M., Jasmi, K.A., Noor, S.S.M., Safar, J., Mohamed, A.K., Embong, W.H.W., Mohamad, A.M., Hehsan, A., Basiron, B., Ihwani, S.S., Maseleno, A., Muslihudin, M., Satria, F., Irawan, D., and Hartati. S. (2018). Determination of the best quail eggs using simple additive weighting. International Journal of Engineering and Technology. 7(2.27), 225-230.

Abadi, S., Huda, M., Hehsan, A., Mohamad, A.M., Basiron, B., Ihwani, S.S., Jasmi, K.A., Safar, J., Mohamed, A.K., Embong, W.H.W., Noor, S.S.M., Brahmono, B., Maseleno, A., Fauzi, A.N., Aminudin, N., and Gumanti, M. (2018). Design of online transaction model on traditional industry in order to increase turnover and benefits. International Journal of Engineering and Technology. 7(2.27), 231-237.

Abadi, S., Huda, M., Basiron, B., Ihwani, S.S., Jasmi, K.Ä., Hehsan, Å., Safar, J., Mohamed, A.K., Embong, W.H.W., Mohamad, A.M., Ňoor, S.S.M., Novita, D., Maseleno, A., Irviani, R., Idris, M., and Muslihudin, M. (2018). Implementation of fuzzy analytical hierarchy process on notebook selection. International Journal of Engineering and Technology. 7(2.27), 238243.

Septiropa, Z., Osman, M.H., Abd. Rahman, A.B., Ariffin, M.A.M., Huda, M., and Maseleno, A. (2018). Profile of cold-formed steel for compression member design a basic combination performance. (2018). International Journal of Engineering and Technology. 7(2.27), 284-290.
Aminudin, N., Fauzi, Huda, M., Hehsan, A., Ripin, M.N., Haron, Z., Junaidi, J., Irviani, R., Muslihudin, M., Hidayat, S., Maseleno, A., Gumanti, M., and Fauzi, A.M. (2018). Application program learning based on android for students experiences. International Journal of Engineering and Technology. 7(2.27), 194-198.

Abadi, S., Teh, K.S.M., Huda, M., Hehsan, A., Ripin, M.N., Haron, Z., Muhamad, N.H.N. Rianto, R., Maseleno, A. Renaldo, R., and Syarifudin, A. (2018). Design of student score application for assessing the most outstanding student at vocational high school. International Journal of Engineering and Technology. 7(2.27), 172-177.

Ristiani, Pardimin, Teh, K.S.M., Fauzi, A., Hananto, A.L., Huda, M., Muslihudin, M., Shankar, K., and Maseleno, A. (2018). Decision Support System Model for Selection of Best Formula Milk for Toddlers Using Fuzzy Multiple Attribute Decision Making. Journal of Advanced Research in Dynamical and Control Systems. Special issue 2, pp. 2075-2088.

Fauzi, Huda, M., Teh, K.S.M., Haron, Z., Ripin, M.N., Hehsan, A., Abas, H., Hehsan, M.R., Irawan, J., and Maseleno, A. (2018). The Design of Fuzzy Expert System Implementation for Analyzing Transmissible Disease of Human. International Journal of Pharmaceutical Research. 10(4),68-78.

Abadi, S., Huda, M., Teh, K.S.M., Haron, Z. Ripin, M.N., Hehsan A. Sarip S., Hehsan, M.R., Amrullah, M., and Maseleno, A. (2018). Hazard Level of Vehicle Smoke by Fuzzy Multiple Attribute Decision Making with Simple Additive Weighting Method. International Journal of Pharmaceutical Research. 10(4),58-71.

Pardimin, Apriadi, Ninsiana, W. Dacholfany, M.I., Kamar, K., Teh, K.S.M., Huda, M., Hananto, A.L., Muslihudin, M., Shankar, K., and Maseleno, A. (2018). Developing Multimedia Application Model for Basic Mathematics Learning. Journal of Advanced Research in Dynamical and Control Systems. 10(14), 1347-1356.

Hamid, A., Sudrajat, A., Kawangit, R. M., Don, A. 'G., Huda, M., Jalal, B., ... \& Maseleno, A. (2018). Determining basic food quality using SAW. International Journal of Engineering \& Technology, 7(4), 3548-3555.

Sari, N.Y., Huda, M., Teh, K.S.M., Ristiani, and Maseleno, A. (2018). Decision support system model for selection of best formula milk for toddlers using fuzzy multiple attribute decision making. International Journal of Engineering \& Technology. 7(4), 3556-3562

Oktafianto, Sudrajat, A., Kawangit, R.M. Don, A.G., Huda, M., Saputri, A.D., and Maseleno, A. (2018). Determining housing location using weighted product International Journal of Engineering \& Technology. 7(4), 3563-3568.

Mulawarman, A., Sudrajat, A., Hendri, N., Kamar, K., Mulyadi, D., Budiyanto, G.' Huda, M., and Maseleno.'(2018). FMẢDM for determining superior commodity at agroindustry area. International Journal of Engineering \& Technology, 7(4), 46674673.

Anggraeni, E.Y., Pardimin, Dacholfany, M.I., Akla, Huda, M., Teh, K.S.M., Hehsan, 
A., Junaidi, J., Yusof, F.M., Abas, H., Husin, M.F.A., Apriani, D., and Maseleno, A. (2018). Modelling effectivenes of IS learning methodology with AHP method. International Journal of Engineering \& Technology, 7(4), 4708-4714.

Budiyanto, G., Ipnuwati, S., Al Gifari, S.A., Huda, M., Jalal, B., Maseleno, A., and Hananto, A.L. (2018). Web based expert system for diagnosing disease pest on banana plant. International Journal of Engineering \& Technology, 7(4), 47154721 .

Manikandan, V., v. Porkodi, amin salih mohammed, and m. Sivaram. "Privacy Preserving Data Mining Using Threshold Based Fuzzy Cmeans Clustering." ICTACT Journal on Soft Computing 9, no. 1 (2018).

Deepa.S, Sivaram.M, "Enabling Anonymous Endorsement In Clouds With Decentralized Access Control", International Journal of Scientific Engineering and Applied Science (IJSEAS) - Volume-1, Issue-3, June 2015, 397-401.

Sivaram.M, Obulatha.O, " Position Privacy Using LocX", International Journal of Innovative Research in Engineering Science and Technology, Vol. III,Issue 01,Pp 206212.

M. Sivaram, K. Batri, Amin Salih Mohammed and V. Porkodi, "Exploiting the Local Optima in Genetic Algorithm using Tabu Search", Indian Journal of Science and Technology, Vol 12(1), DOI: 10.17485/ijst/2018/v12i1/139577, January 2019.

Sivaram M, Batri K, "Odd and Even Point Crossover Based Tabu GA for Data Fusion in InformationRetrieval", http://hdl.handle.net/10603/38935, 10-Apr2015.

Sivaram.M, Yuvaraj.D, Amin Salih Mohammed, Porkodi.V' "Estimating the Secret Message in the Digital Image" International Journal of Computer Applications, 181(36):26-28, January 2019.

Mrs.V.Porkodi, Dr.D.Yuvaraj, Dr.Amin Salih Mohammed,V.Manikandan and M.Sivaram, "Prolong the Network Lifespan of Wireless Sensor Network by Using Hpsm", International Journal of Mechanical Engineering and Technology, 10(01), 2019, pp.2039-

2045.http://www.iaeme.com/IJMET/issues.a sp?JType $=$ IJMET $\&$ VType $=10 \&$ Type $=01$

Porkodi.V, Yuvaraj.D., Mohammed,A.S, Sivaram.M and Manikandan.V," IoT in Agriculture" Journal of Advanced Research in Dynamical and Control Systems, Pages: 1986-1991,14-Special Issue, Pages: 19861991,2018.

Manikandan.V, Mohammed, A.S, Yuvaraj,D., Sivaram.M and Porkod.V, "An Energy Efficient EDM-RAEED Protocol for IoT Based Wireless Sensor Networks" Journal of Advanced Research in Dynamical and Control Systems, Pages: 1992-2004,14Special Issue, Pages: 1992-2004, 2018.

Mohammed, A.S., Kareem, S.W., Al Azzawi, A.K., Sivaram, M. "Time series prediction using SRE-NAR and SREADALINE", Journal of Advanced Research in Dynamical and Control Systems, Pages: 1716-1726, 2018.
Sivaram, M., Yuvaraj, D., Porkodi, V., Manikandan, V. "Emergent news event detection from facebook using clustering" Journal of Advanced Research in Dynamical and Control Systems, Pages:1941-1947, 2018.

Nithya, S., Sundara Vadivel, P., Yuvaraj, D., Sivaram, M. "Intelligent based IoT smart city on traffic control system using raspberry $\mathrm{Pi}$ and robust waste management", Journal of Advanced Research in Dynamical and Control Systems, Pages: 765-770, 2018.

Viswanathan, M., Sivaram, M., Yuvaraj, D., Mohammed, A.S. "Security and privacy protection in cloud computing", Journal of Advanced Research in Dynamical and Control Systems, Pages 1704-1710, 2018

Batri, K., Sivaram, M. "Testing the impact of odd and even point crossover of genetic algorithm over the data fusion in information retrieval", European Journal of Scientific Research, 2012.

Sivaram Yuvaraj Amin Salih Mohamme M D V Porkodi. Estimating the Secret Message in the Digital Image. International Journal of Computer Applications 181(36):26-28, January 2019 